\title{
APPEAL FOR SUPPORT FOR THE INDEX HOLMENSIS PROJECT
}

The INDEX HOLMENSIS is an index of plant distribution maps with world-wide coverage. It is the only international bibliography on distribution of vascular plants in area and vegetation maps.

We have so iar published four volumes, i.e. volume I, covering vascular cryptogams and gymnosperms, volume II containing Monocotyledoneae A-I, volume III Monocotyledoneae $\mathrm{J}-\mathrm{Z}$, and finally volume IV covering Dicotyledoneae A-B, together more than 1000 pages. We intend to continue to publish one volume each year. The total number of distribution maps so far published is estimated at about 400,000 , all of which will finally be listed in the index or its supplement. Although the main work is at present done at the Swedish Museum of Natural History in Stockholm, the indexing work is served by an international editorial board. Members of this board to some extent guarantee completeness of the file for their particular area.

Still, the number of area and vegetation maps published annually is growing rapidly owing to the increased importance that is felt for the geographic compound of plant taxa. Consequently, not only are there wide areas all over the world where the entire flora is mapped systematically, but mapping has become a common feature in monographs in different fields, as for instance economic botany, palaeobotany, vegetational history, palynology, and last but not least phytocoenology.

In order to keep the file for the INDEX HOLMENSIS and its planned supplement volumes up-to-date we herewith ask our fellow botanists to inform us about their published maps and/or to send reprints of their publications. Needless to say, we shall also continue to supply all information on distribution maps so far not published in the INDEX HOLMENSIS to colleagues on request.

All correspondence should be addressed to: Hans Tralau, The Swedish Museum of Natural History, S - 10405 Stockholm 50 .

Volume 77, No. 810, including pages 165-336, was issued Sept. 30, 1975 


\section{$2 \mathrm{BHL}$ Biodiversity Heritage Library}

Tralau, Hans. 1975. "APPEAL FOR SUPPORT FOR THE INDEX HOLMENSIS PROJECT." Rhodora 77, 336-336.

View This Item Online: https://www.biodiversitylibrary.org/item/14697

Permalink: https://www.biodiversitylibrary.org/partpdf/189492

\section{Holding Institution}

Missouri Botanical Garden, Peter H. Raven Library

\section{Sponsored by}

Missouri Botanical Garden

\section{Copyright \& Reuse}

Copyright Status: In copyright. Digitized with the permission of the rights holder.

License: http://creativecommons.org/licenses/by-nc-sa/3.0/

Rights: https://biodiversitylibrary.org/permissions

This document was created from content at the Biodiversity Heritage Library, the world's largest open access digital library for biodiversity literature and archives. Visit BHL at https://www.biodiversitylibrary.org. 